\title{
Digitalist Literacy in Women's Micro, Small, Medium Enterprises (UMKM) in the Midst of the Covid-19 Crisis: Conceptual Paper
}

\author{
Andi Widiawati ${ }^{1, *}$, Idayanti Nursyamsi ${ }^{2}$, Fauziah $^{3}$, Wahda $^{4}$ \\ ${ }^{1}$ ITB Nobel Indonesia Makassar, Indonesia \\ ${ }^{2}$ Universitas Hasanuddin, Indonesia \\ ${ }^{3}$ Universitas Hasanuddin, Indonesia \\ ${ }^{4}$ Universitas Hasanuddin, Indonesia \\ ${ }^{*}$ Corresponding author.Email: widiawati1972@gmail.com
}

\begin{abstract}
This paper aims to understand and explore how women business owners in MSMEs who join participatory study groups and discussion groups know how to use and utilize social media and embrace digitalization during the crisis due to the Covid-19 pandemic to maintain business viability. Design / methodology / approach - Combining theoretical and practical knowledge perspectives from the results of previous research on groups of women entrepreneurs in small businesses, used to respond to the phenomenon of women entrepreneurs to be able to adapt to an increasingly digital business world, digital learning on the use of social media and digital skills continue to be developed. This study uses qualitative methods to increase understanding of how women entrepreneurs gain digital skills to keep up with the digital revolution. There are many ways to be able to keep up with changes in the business world, groups of women entrepreneurs in small businesses do it by practicing while learning, informal learning from various sources, and continuing to learn step by step is the path taken to continue to develop themselves. The results of this study provide a direction in order to stay alive and develop and win the competition in business, women business owners must continuously learn new knowledge and skills through the use of Participatory Action Research (PAR) and Focus Group Discussion (FGD) methods to be able to seize profit opportunities. From the aspect of using digital in running a business, especially to capture the potential for digitalization, the application of new knowledge and mastery of the means of connecting between producers and consumers must be owned by a group of women business owners, this is a choice of life or death.
\end{abstract}

Keywords: digital literacy, women entrepreneurs (MSMEs), Covid-19.

\section{INTRODUCTION}

The pandemic crisis has harmed the performance of women's Micro, Small and Medium Enterprises (MSMEs) in terms of production, marketing, product distribution, turnover, profits, depleted capital, difficulty accessing capital, and difficulty obtaining raw materials [1]. Based on Data on the Development of Micro, Small, Medium and Large Enterprises in Indonesia in the 2014-2018 periode.

99.99 percent of the 64 million business units in Indonesia are Micro, Small and Medium Enterprises (MSMEs). Around $60 \%$ of the number of MSMEs are managed by women. As for the 3 (three) sectors controlled, namely fashion, culinary and crafts, "Women who are able to survive during the pandemic are $50 \%$ culinary business, $20 \%$ basic food business, $10 \%$ craft business, and $10 \%$ floriculture business [2]. As a key response to environmental change, capacity building related to aspects of digitalization is emphasized as a contributor to the survival and success of women's MSME businesses in an uncertain environment [3]. The main problem that exists in women entrepreneurs is the lack of mastery and low technology and information literacy in the women's MSME group has become an open secret. The main problem cannot be separated from gender stereotypes and inequality of access between men and women, thus preventing women from getting the opportunity to learn, benefit and have a career in the field of information technology [4]. This is where the role of stakeholders, especially the government and business groups, is to 
continue to encourage the development of MSMEs and to optimally facilitate the use of information technology, both in terms of providing training or providing technological facilities. MSME Women's sources of information technology knowledge so far: 87 percent self-study, 35 percent being taught by friends and family, 34 percent participating in MSME community training, 20 percent receiving government training, and 9 percent receiving training from civil society groups) [5]. The main role of women MSMEs remains to be the spearhead for self and business development through the role of continuous adaptation through independent learning and contributing with new insights about the behavior and ways of women entrepreneurs to acquire digital skills to offset digitalization, learning by doing, informal learning and development steps. self gradually becomes a necessity [6].

\section{LITERATURE REVIEW}

Digital literacy, according to Potter, refers to people's interest in, attitude toward, and ability to use digital technology and communication tools to acquire, manage, integrate, analyze, and evaluate information, build new knowledge, create, and communicate with others in order to actively participate in society. According to Potter, creating a digital-based society entails not just introducing digital media but also integrating them into daily activities (including organizations) in order to increase efficiency [7].

In their research on the Role of Women in the Future of Employment in Indonesia, Desintha Dwi Asriani and Herni Ramdlaningrum observed that, at a time when digitalization and automation are advancing, it is essential and urgent to equip women and girls with STEM (science, technology, engineering, and mathematics) knowledge [4]. His research discovered that in Indonesia, digitalization is still viewed as a change of traditional business practices, rather than a comprehensive business transfer that leads to market dominance. Women are left behind as a result of a lack of awareness and use of this digital platform, which is inextricably linked to gender. Prejudices and inequity that prevent women and girls from pursuing STEM occupations [8]. Sulhan, Suhail's MSME study is included. Social media and promotions are more likely to aid women in crisis than other strategies for reducing lost sales during the crisis [9].

As a result of digitalization, sociocultural transformation has a negative impact on small enterprises and entrepreneurs becauseIt has the potential to create new growth prospects., especially in light of information and communication technology, ICT as a channel of communication, marketing, and
transactionsWomen entrepreneurs' awareness and use of social media, according to Anna Karin Olsson and Iréne Bernhard's study [1]. Several studies, however, highlight the fact that small business owners, Entrepreneurs, for example, rarely have all of the knowledge and abilities needed to develop a company and deal with social digital challenges. The outcomes of the study suggest that a continual desire to expand one's firm by adapting to ongoing digitization characterizes entrepreneurial behavior [6].

Riskin Hidayat, Siti Alliyah in her research examines the choice of learning the use of digital media in MSMEs is very important to assess the effectiveness of the choice of digitalization media channels. MSMEs can take advantage of existing information technology, namely social media and websites to promote or sell their products, so they can improve their performance, both before the Covid-19 widespread especially during the Covid-19 contagion. His findings show that the information technology used by MSMEs Coffee has a very important role in improving the performance of the coffee business, both before the contagion.and during the Covid-19 contagion [10].

M. Hidayat in his research found that the use of technology in business is one way to manage profitable relationships with consumers and provide convenience to consumers (Kim, Pae, Han, \& Srivastava, 2010). To survive in the midst of the current pandemic, entrepreneurs must be able to work around it. Start focusing on digital marketing through website development that implements e-commerce, utilizing social media and selling through e-marketplaces, or you can also look for a reseller team to sell their products [11]. In their research, D. Dwi Asriani and $\mathrm{H}$. Ramdlaningrum discovered that MSME women entrepreneurs work offline, online, or a combination of the two. Women in SMEs are not benefiting, according to available data. According to data on e-commerce transactions from 2016 to 2017, women small business owners used digital platforms at a low rate, dropping from 42.7 percent to 34.4 percent during that time. (https://katadata.co.id/umkm). Given that 60 percent of Indonesia's 57 million SMEs are owned or headed by women, this number shows the significant differential in women's engagement in the digital economy [4].

Komalasari's research, Rita Harto, Budi Setiawan, Rony, found that during the COVID-19 pandemic, technology played an important role in keeping community activities functioning during the PSBB. Digitizing MSMEs is one of the important keys to making MSMEs survive and expand business and market scale. However, until now, of the approximately 
64 million MSME population in Indonesia, only 13 percent have gone digital (depkop.go.id, 2020) [12].

Based on the aforementioned circumstances, MSMEs in general, and particularly female MSMEs, frequently face challenges when it comes to using digital technology to access, manage, integrate, analyze, and evaluate information, gain new expertise, and create and communicate with others. On the other hand, the performance of digital-based MSME companies will be optimized, and they will side with women (or, in other words, have a gender perspective) [7]. Based on this study sustainable growth and development for women entrepreneurs to learn new digital technology skills on a constant basis in order to fully exploit the potential of digitalization, particularly in terms of social media understanding and use, through Participatory Action Research (PAR).

\subsection{Theoretical Basis}

The concept of Diffusion theory. The diffusion of innovation theory becomes relevant as one of the literature studies to deepen the study of this phenomenon. Everett Rogers created the diffusion and innovation theory. Diffusion is an innovative process that is conveyed to members of the social system through certain routes. A concept synergy between technological adoption, digital literacy, MSME growth, and a gender viewpoint is hoped for [7].

Gender equality and stereotypes in the usage of digital media, according to theory in the 18th century, [28] promoted liberal feminism. Pioneered it in the nineteenth century [8], and Friedan in the [19]. The core premise of liberal feminist thought is that because men and women are created equal and have equal rights, they must also have equal opportunities [10]. It is evident that women suffer the brunt of unpaid labor, such as infant care, household tasks, and senior care, putting women's performance at a disadvantage, particularly during the Covid-19 pandemic [13]. Efforts to overcome the digital divide from the gender aspect are not enough just to invest heavily in infrastructure. The World Summit on the Information Society meeting organized by the United Nations has formulated an integrative and sustainable solution in overcoming the problem of the digital divide, namely by building ICT infrastructure, forming an information society, and ICT education. Low literacy is an unavoidable fact of the issue of inequality, equality and gender stereotypes in the use of digital platforms in Indonesia [14].

Davis developed the theory technology acceptance model (TAM) in 1985. Starting with Fishbein and Theory of Reasoned Action (TRA), Theory Planned
Behavior (TPB) has been shown to be efficient in selecting and predicting consumer adoption of technology [15]. The TRA model is the foundation for understanding all human behavior. According to TRA theory, conduct is first determined by a desire to engage in a behavior. Personal perceptions and attitudes, as well as social forces, influence these interests [16]. The perception in the effects of behavioral performance determines attitude. Created two main constructs to the TRA model, namely perceived usefulness and perceived ease of use, to generate the TAM model [17]. This is because a person's acceptance of information technology systems is determined by the usefulness of perception and the ease of use of perception.

The utility of perception and the simplicity with which it can be used have an impact on behavioral intention. MSMEs are also obliged to employ information technology to boost their performance in the current era of disruption.

The usefulness of perception and the ease of use of perception have an influence on behavioral intention. In the current era of disruption, MSMEs are also required to use information technology to improve their performance [18].

\subsection{Adaptation Theory}

Performance adaptation has been defined in various ways, both explicitly and implicitly. For example, discussed it as "changing behavior to meet the demands of a new environment, event or situation" [19]. Allworth and describe it as "behavior that demonstrates ability" to cope with change and transfer learning from one task to another as job demands vary." [20]. To function effectively in this shifting and diversified environment, workers must become more adaptive, versatile, and tolerant of uncertainty [21].

\section{ANALYSIS METHOD}

Women entrepreneurs have real challenges when it comes to running businesses that rely on digital technology, such as the inability to acquire, manage, integrate, analyze, and evaluate information, as well as the inability to create and engage with others. The notion of Participatory Action Research (PAR) is presented in this paper as a concept that is carried out in a participatory manner among citizens in a community or wider social sphere in order to stimulate transformative acts (changes in better living conditions). PAR stands for "research by, with, and for people," not "research on people" [22]. The research method, the action dimension, and the participation dimension are the three main pillars of PAR. This means that PAR must be 
carried out using research design approaches, with the objective of encouraging transformative action, and with as many citizens or community members as feasible as PAR implementers. The PAR idea is based on a set of theoretical principles: 1. Participation. This principle requires that PAR be carried out as participatory as possible, involving anyone with an interest. 2. Action Orientation. This principle demands that all activities in PAR must direct citizens to take transformative actions that change their social conditions for the better. 3 . Triangulation. PAR must be carried out using various perspectives, methods, and different work tools to understand the same situation, so that the understanding of the research team and the community towards the situation is more complete and in accordance with the facts. Flexible or Flexible. Even though PAR is carried out with very careful planning and careful or careful implementation, researchers and residents must remain flexible in dealing with sudden changes in the situation [23].

To support the proposed model, techniques that support the application of the concept are needed. In this case, using the Focus Group Discussion technique is one of the most well-known qualitative research methods besides the interview technique. FGD is a focused discussion of a group to discuss a particular problem, in an informal and relaxed atmosphere. (FGD) to explore the problems and needs of the target subjects. which focuses on discussing solutions to different issues [24].

Participatory Action Research (PAR) Procedures 1). Preliminary mapping) Apply preliminary mapping to have an effective understanding of the people. 2) Establishing human relations, inculturation, and trust with the community in order to form an equitable and mutually beneficial collaboration. 3) Establishing a Social Change Research Agenda 4) Participatory Mapping (participatory mapping) 5) Identifying and Understanding Humanitarian Issues 6) Designing Community Movement Plans, which include constructing movement plans to mitigate pre-defined humanitarian issues. 7) Community Organizing with the cooperation of lecturers and students PKM is a company that develops social institutions. 8) Considering the First Steps Towards Change, Problem-solving actions are carried out in parallel and in a participative way. 9) Establishing Community Learning Centers based on the needs of community partners that have already begun to effect change. 10) Reflection (Social Change Theory): The community reflects on all of the procedures and outcomes (from beginning to end). 11) Increasing the Movement's and Support's Scale The success of the Transformatif PKM program is determined not only by the outcomes of activities carried out during the process, but also by the program's long-term viability [25].

\subsection{Benchmarks for PAR Success}

A cycle is used as a characteristic for the success of the community empowerment-based research process in PAR theory. KUPAR is the designation of the cycle (to Know, to Understand, to Plan, to Action and to Reflection). (1). To Know (to Know) is the first step in empowerment, which means the process of the researcher's information concerning the life of the group under research. (2) To Understand (to understand) is defined as a process where researchers and empowered communities are able to identify the problems that exist in the community. (3) To Plan (to plan) is defined as the process of planning strategic actions in solving problems that arise in society. (4) To Action (launching action) is the implementation of the product of the community's thinking to build, manage, change optimally solutions. (5) To Reflection (reflection) is the stage where researchers and the community evaluate and monitor the empowerment actions that have been carried out so that empowerment becomes directed and measurable [26].

\subsection{Focus Group Discussion (FGD)}

Other research techniques that support Participatory Action Research's research needs (PAR). FGD is a type of discussion that is used to find out information about the participants' wants, needs, points of view, beliefs, and experiences. The following is the procedure for implementing the FGD: 1) The FGD is being prepared. The number of participants is made a decision by the facilitator. 2) Determines the FGD group's composition. 3) Select the location for the focus group discussion. 4) Seating design. 5) Create invitations; 6) Begin training facilitators [27]. FGDs can be implemented as a data collection method on their own. Viswanathan and Jain (2013) conducted an exploratory study using six focus groups to construct a decision-making framework. Hennk: 2014 has described several uses of FGD which can be classified as: (1) assessment focus; (2) focus of explanation; and (3) Pay attention to the context. FGDs have the distinct advantage of observing the group process as participants interact with each other and with the facilitator when discussing a topic; strategies used to influence each other; socially accepted norms around the research topic and deviations, if any, and how these deviations are controlled by the group. The focus groups gave us a glimpse into the participants' social environments, as well as a quick review of the contextual and cultural aspects that influenced the research issue [28].

\section{RESULT AND DISCUSSION}

The results of the analysis of literature review in the literature review that emphasize the importance of 
literacy for women entrepreneurs in managing their businesses: Digital literacy has an essential part in the continuation of women's activities, according to studies, and the process of adopting an innovative technology boosts women's ability to expand MSME activities [29].

There are several deficiencies that must be answered based on this paper's review of the literature. First, because no empirical trials or tests have been conducted, the conceptual model that has been presented and collated is based on a study of the relevant literature. The goal or purpose of this study, is to present a comprehensive conceptual understanding of the topic of Digitalis Literate among Women MSME Entrepreneurs [30].

One of the most difficult during a pandemic is providing an efficient, consistent, and timely communication platform to build resilience to the shocks caused by the pandemic. Thanks to social computing, the rapid expansion of social media has created a powerful platform and new horizons for studying and using the possibilities of collaborative work during disasters and emergencies. There has been a substantial shift in individual and collective social behavior as a result of the widespread acceptance of social media and the continued rise of its applications and uses [31].

The theory in this qualitative conceptual paper will be practical as a tool to be able to understand the social context better broad and deep such as the concept of Technology Acceptance Model (TAM), Diffusion Theory, Gender Equality and Stereotypes on Digital Platforms, Adaptation Theory, Model Concepts in Participatory Action Research (PAR), Focus Group Discussion (FGD). Approach a theory of science certain to interpret research findings and not to prove the truth of a theory [32]. In qualitative research, usability is extremely crucial. Theories in qualitative research used to allow and assist qualitative researchers in understanding what is intuitively known from the outset, but as social theory evolves, the following phase can change.

Digital literacy is carried out as an effort to build understanding at the level of human resource development for MSME entrepreneurs related to understanding the existence of digital media. In addition to the cognitive aspect, efforts have been made to implement the practical use of digital media in a positive direction. Through digital literacy, people not only introduce digital media, they are able to synergize with daily activities, especially to support their productive business activities. Digital literacy can be a road map for other women who are struggling in the MSME business to re-enter the business.

\section{Future Research}

When you consider the limits that have been presented in regard to the topics raised in this work, you will see that there are limits in the analysis of how digitalization literacy has impacted women in micro, small, and medium firms due to a lack of adequate. The proposed model can be utilized to create a model for empirical study

\section{ACKNOWLEDGMENTS}

Thank you to colleagues who have helped and provided moral and material support so that this conceptual paper can be realized. Do not forget to say the same to the supervisors, as well as all those who have helped and provided moral and material support so that this dissertation research can be carried out.

\section{REFERENCES}

[1] M. Portuguez Castro and M. G. Gómez Zermeño, "Being an entrepreneur postCOVID-19 - resilience in times of crisis: a systematic literature review," J. Entrep. Emerg. Econ., 2020, doi: 10.1108/JEEE-07- 20200246.

[2] G. Grandy, W. Cukier, and S. Gagnon, "(In)visibility in the margins: COVID-19, women entrepreneurs and the need for inclusive recovery," Gend. Manag., 2020, doi: 10.1108/GM-07-2020-0207.

[3] D. Dwi Asriani and H. Ramdlaningrum, "Examining Women's Roles in the Future of Work in Indonesia," 2019.

[4] PRAKARSA, "The Impact Of Covid-19 On Women-Led MSMES," no. November, pp. 2-5, 2020.

[5] A. K. Olsson and I. Bernhard, "Keeping up the pace of digitalization in small businessesWomen entrepreneurs' knowledge and use of social media," Int. J. Entrep. Behav. Res., 2020, doi: 10.1108/IJEBR-10-2019-0615.

[6] T. P. Widyastuti, D. A. R., Nuswantoro, R., \& Sidhi, "Literasi Digital Pada Perempuan Pelaku Usaha," J. ASPIKOM, vol. 3(1), pp. 1-15, 2015.

[7] K. Saleh Al-Omoush, M. Orero-Blat, and D. Ribeiro-Soriano, "The role of sense of community in harnessing the wisdom of crowds and creating collaborative knowledge during the COVID-19 pandemic," J. Bus. Res., no. October, 2020, doi: 10.1016/j.jbusres.2020.10.056.

[8] S. Sultan and W. I. M. Sultan, "Women MSMEs in times of crisis: challenges and 
opportunities," J. Small Bus. Enterp. Dev., vol. 27, no. 7, pp. 1069- 1083, 2020, doi: 10.1108/JSBED-06-2020-0226.

[9] R. Hidayat and S. Alliyah, "Hubungan Gender, Teknologi Informasi dan Kinerja UMKM Kopi," J. Akunt. dan Manaj., vol. 18, no. 01, pp. 9-21, 2021, [Online]. Available: https://stei.ac.id/ojsstei/index.php/JAM/article/ view/373.

[10] M. Hidayat, F. Latief, S. Bahasoan, A. Widiawati, and D. A. Nianty, "Factors Influencing Resilience of Micro Small and Medium Entrepreneur (MSME) during COVID 19 Outbreak in South Sulawesi Province Indonesia," TEST Eng. Manag., vol. 83, no. may-June 2020, pp. 26 707-26721, 2020, doi: 10.31219/osf.io/cme2j.

[11] R. Komalasari, B. Harto, and R. Setiawan, "UMKM Go-Digital sebagai Adaptasi dan Inovasi Pemasaran Arkha Minoritas pada Pandemi COVID-19," IKRAITH-ABDIMAS Vol 4 No 1 Bulan Maret 2021, vol. 4, no. 59, pp. 17, 2020.

[12] M. Lazić, O. Jovanović, and M. LazarevićMoravčević, "Women's entrepreneurship in the wake of the covid19 crisis: The case of Serbia," J. Women's Entrep. Educ., vol. 2021, no. 1-2, pp. 56- 69, 2021, doi: 10.28934/jwee21.12.pp56-69.

[13] Sasakawa Peace Foundation, Asia Women Impact Fund, and Dalberg, "A genderinclusive Southeast Asia through entrepreneurship," 2019, [Online]. Available: https://www.spf.org/globaldata/user53/G50report1.pdf.

[14] A. Pamuji, "Pengembangan Model Penerimaan Teknologi Termodifikasi Pada Persepsi Jarak Sosial, dan Persepsi Jarak fisik," J. Sist. Cerdas, vol. 03, no. 02, pp. 165-175, 2020, [Online]. Available:

https://apic.id/jurnal/index.php/jsc/article/view/1 32.

[15] K. Aulia, R. Hartanto, and S. Fauziati, "Model Konseptual Faktor-faktor yang Mempengaruhi Pengelolaan Konten Website pada Pemerintah Daerah," Pros. Semin. Nas. Ilmu Komputer. (SNIK 2016) Res. Innov. Data Min. Green Technol., no. Snik, pp. 247-254, 2016.

[16] D. K. Jundt, M. K. Shoss, and J. L. Huang, "Individual adaptive performance in organizations: A review," J. Organ. Behav., vol. 36, no. S1, pp. S53-S71, 2015, doi: 10.1002/job.1955.

[17] S. K. Baard, T. A. Rench, and S. W. J.
Kozlowski, Performance Adaptation: A Theoretical Integration and Review, vol. 40, no. 1. 2014.

[18] E. D. Pulakos, S. Arad, M. A. Donovan, and K. E. Plamondon, "Adaptability in the workplace: Development of a taxonomy of adaptive performance," J. Appl. Psychol., vol. 85, no. 4, pp. 612-624, 2000, doi: 10.1037/0021-9010.85.4.612.

[19] A. Rahmat and M. Mirnawati, "Model Participation Action Research Dalam Pemberdayaan Masyarakat," Aksara J. Ilmu Pendidik. Nonform., vol. 6, no. 1, p. 62, 2020, doi: 10.37905/aksara.6.1.62-71.2020.

[20] C. Alexander et al., Participatory diagramming: A critical view from North East England. 2007.

[21] T. B. G. Egziabher and S. Edwards, "Participatory Action Research (Par) Metodologi Alternatif Riset Dan Pengabdian Kepada Masyarakat Transformatif," Africa's potential Ecol. Intensif. Agric., vol. 53, no. 9, pp. 16891699, 2013.

[22] A. Paramita and L. Kristiana, "Teknik Focus Group Discussion dalam Penelitian Kualitatif," Tek. Focus Gr. Discuss. dalam Penelit. Kualitatif, vol. 16, no. 2, pp. 117-127, 2013, doi: 10.22435/bpsk.v16i2.

[23] S. Manoranjitham and K. S. Jacob, "Focus group discussion.," Nurs. J. India, vol. 98, no. 6, pp. 125- 127, 2007, doi: 10.1108/978-178973-973- 220191007.

[24] S. Rijal, M. I. Said, N. Arisah, and M. Hasan, "Digital Generation For Digital Nation," pp. 2-7, 2021.

[25] S. Aisyah, "Dampak Pandemi COVID-19 Bagi UMKM Serta Strategi E-Marketing UMKM di Indonesia," J. Chem. Inf. Model., vol. 53, no. 9, pp. 3-9, 2020.

[26] R. Rosita, "Pengaruh Pandemi Covid-19 Terhadap Umkm Di Indonesia," J. Lentera Bisnis, vol. 9, no. 2, p. 109, 2020, doi: 10.34127/jrlab.v9i2.380.

[27] F. M. Cesaroni and D. Consoli, "Are Small Businesses Really Able to Take Advantage of Social Media?: Discovery Service para Universidad Del Pacífico," Electron. J. Knowl. Manag., vol. 13, no. 4, pp. 257-268, 2015, [Online]. Available: http://eds.a.ebscohost.com/eds/detail/detail?vid $=7 \& \quad$ sid=4e81756c-b6dd-4446-b9087812ed022294\%40sessionmgr4007\&bdata $=\mathrm{Jm}$ $\mathrm{xhb}$ mc9ZXMmc210ZT11ZHMtbG12ZSZzY29wZT 
1 zaX Rl\#AN=112001073\&db=lih.

[28] S. P. Foundation, “Growing Women's Entrepreneurship through ICT in Southeast Asia," p. 39, 2017.

[29] S. L. Murphy, "Individual adaptability as a predictor of job performance," Diss. Abstr. Int. Sect. A Humanity. Soc. Sci., vol. 77, no. 4-A(E), p. No- Specified, 2016, [Online]. Available: http://ovidsp.ovid.com/ovidweb.cgi?T=JS\&PA $\mathrm{GE}=\mathrm{r}$ eference $\& D=$ psyc $13 \& N E W S=N \& A N=2016$ 37856-006.

[30] A. Arslan, I. Golgesi, Z. Khan, O. Al-Tabbaa, and $P$. Hurmelinna-Laukkanen, "Adaptive learning in cross-sector collaboration during global emergency: conceptual insights in the context of COVID-19 pandemic," Multinatl. Bus. Rev., vol. 29, no. 1, pp. 21-42, 2020, doi: 10.1108/MBR-07-2020-0153.

[31] T. Agustina, W. Gerhana, and S. Sulaiman, "The Effect of Locus of Control, Learning, and Adversity Quotient Towards Micro Business Success," J. Wetl. Environ. Manag., vol. 8, no. 1, pp. 21-32, 2020.

[32] H. U. Zabel, "A model of human behavior for sustainability," Int. J. Soc. Econ., vol. 32, no. 8, pp. 717-734, 2005, doi: $10.1108 / 03068290510608228$ 